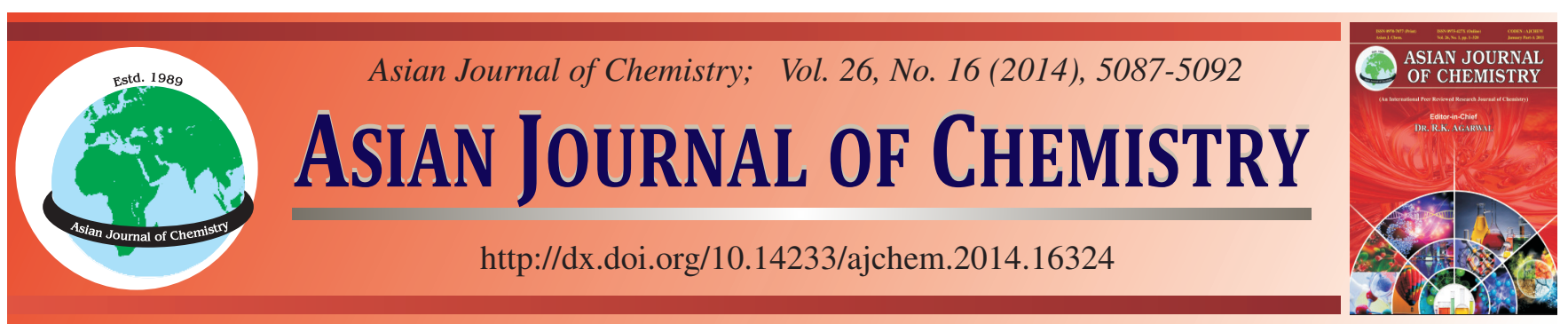

\title{
Improvement of Antioxidant Activity of Whey Protein Hydrolyzate by Conjugation with Glycosylation
}

\author{
Changyan Sun ${ }^{1,2}$, Dehai Li ${ }^{3}$, Qian Liu ${ }^{1}$ and BaOhua Kong ${ }^{1,4, *}$
}

${ }^{1}$ College of Food Science, Northeast Agricultural University, Harbin 150030, Heilongjiang Province, P.R. China ${ }^{2}$ Heilongjiang Dairy Industry Technical Development Center, Harbin 150028, Heilongjiang Province, P.R. China ${ }^{3}$ College of Forest, Northeast Forestry University, Harbin 150040, Heilongjiang Province, P.R. China ${ }^{4}$ Synergetic Innovation Center of Food Safety and Nutrition, Wuxi, Jiangsu Province, P.R. China

*Corresponding author: Tel/Fax: +86 451 55191794; E-mail: kongbh63@ hotmail.com

This study was conducted to investigate the antioxidant activity of whey protein hydrolyzate by conjugation with glucosylation. The reaction conditions of whey protein hydrolyzates conjugated with glucose were optimized with the response surface methodology using the central composite rotatable design. The optimisation parameters studied were glucose concentration $8 \%$, temperature $94{ }^{\circ} \mathrm{C}$ and reaction time $3.2 \mathrm{~h}$. Under this optimum condition, the reducing power, hydroxyl radical scavenging activity, scavenging of the ABTS radical, copper and iron chelating, thiobarbituric acid-reactive substances of whey protein hydrolyzates by conjugation with glucose through Maillard reaction are higher than whey protein hydrolyzates. The result showed that whey protein hydrolyzates by conjugation with glucose had high antioxidant activities.

Keywords: Glycosylation, Glucose, Whey protein hydrolyzates, Antioxidant activity, Response surface methodology.

\section{INTRODUCTION}

Whey protein isolate (WPI), a by-product from cheese industry, owns high content of nutritional constituents and excellent functional properties, such as emulsifying, foaming and gelation. So milk whey proteins are an important source of ingredients used in a wide variety of products ${ }^{1}$. Whey proteins are globular proteins such as $\beta$-lactoglobulin $(\beta-\mathrm{Lg})$, $\alpha$-lactalbumin $(\alpha$-La), bovine serum albumin (BSA) and immunoglobulins, with $\beta$-lactoglobulin being the major component, largely responsible for the functionality of the total whey protein system. Inspite of the beneficial properties of whey proteins, many modifications have been used to further improve their functionality through physical, chemical or enzymatic treatments to obtain ingredients with new applications. However, some of these methods require noxious chemical reagents, which limit the use of such modified proteins as food ingredients ${ }^{2,3}$. An effective method to improve the functional properties of proteins, which does not require chemical catalysis, relies on the interaction of proteins with polysaccharides and smaller carbohydrates via Maillard reaction ${ }^{4}$.

Reports on the conjugation of whey proteins with polysaccharides via Maillard reaction are scarce. There were some reports that conjugates of $\beta$-lactoglobulin and dextran $(43 \mathrm{kDa})$ exhibited improved solubility and thermal stability ${ }^{5}$. Complexes of $\beta$-lactoglobulin with dextran also gave emulsions with excellent stability ${ }^{6}$, which increased with the polysaccharide size up to $150 \mathrm{kDa}^{7}$. Similarly, the emulsifying activity and solubility of BSA greatly increased on conjugation with galactomanan $(22 \mathrm{kDa})$.

The final functional properties of the protein-polysaccharide conjugates obtained via Maillard reaction depend on the protein conformation, as well as on the particular characteristics of the polysaccharide ${ }^{8,9}$. As compared to larger molecules whey protein, the low reactivity of the polysaccharides by the attached molecules limits the extent of the Maillard reaction and diminishes subsequent reactions. Whey protein hydrolyzates with enzyme can produce small molecular proteins and can enhance the reactivity of the polysaccharides.

Several proteins, such as whey proteins, $\beta$-lactoglobulin, ovalbumin, lysozyme, rice proteins and soy proteins, have been conjugated with various sugars, in order to improve their functionality and heat stability properties ${ }^{10-14}$. $\beta$-Lactoglobulin modified by saccharides showed stronger radical-scavenging activity and/or can influence microorganism growth, therefore having the potential to be used as a food preservation additive. However, little information is available about the antioxidant activity by the interaction of whey protein hydrolyzates and 
polysaccharides. The aim of this study is to evaluate the antioxidant activity of interaction of whey protein hydrolyzates with polysaccharides and via Maillard reaction.

\section{EXPERIMENTAL}

Whey protein isolate (WPI, $95 \%$ protein) was purchased from Davisco Foods International, Inc., (Minnesota, MN, USA). 2,2'-Azinobis(3-ethylbenzothiazoline-6-sulfonic acid ammonium salt) (ABTS), ferrozine, potassium ferricyanide and L-leucine were purchased from Sigma Chemical Co. (St. Louis, MO, USA). All other chemicals used in the present study reagents were of analytical grade.

Preparation of whey protein hydrolyzates (WPH): Whey protein isolate (WPI) solution (5\% protein concentration) was preheated water bath at $95{ }^{\circ} \mathrm{C}$ for 5 min to unfold the protein structure ${ }^{15}$. The heated-treated WPI was then hydrolyzed for $5 \mathrm{~h}$ with Alcalase, the ratio of enzyme to WPI is 2:100 and the enzyme hydrolyzate condition is $\mathrm{pH} 8.5$, at $65^{\circ} \mathrm{C}$. The protein hydrolyzate was lyophilized and stored at $4{ }^{\circ} \mathrm{C}$.

Preparation of WPI hydrolyzate polysaccharides conjugate: Aqueous mixtures of proteins and glucose, lactose and fructose $(1: 1, \mathrm{w} / \mathrm{w})$ was transferred to screw-sealed tubes, tightly capped and heated in water bath (Taisite Instrument, Tianjin, China) at 50, 60, 70, 80 and $90^{\circ} \mathrm{C}$. The samples were heated at different temperature for $0,1,2,3,4,5 \mathrm{~h}$ and then were cooled immediately in iced water. Maillard reaction products (MRPs) were kept at $4{ }^{\circ} \mathrm{C}$ until analysed.

Experimental design: Response surface methodology was used for investigating the influence of three independent variables (temperature, concentration and reaction time; these are the response variables) on reducing power. In the present work, the experiments were performed according to a rotatable central composite design (CCD). Based on the implicit assumption that the errors are uncorrelated with each other and with the independent variables and have equal variance, the method of least-square regression was used to fit the data to a quadratic model $^{16}$. The central $(0)$ and axial $( \pm 1)$ levels of each variable were designated as $-1\left(80{ }^{\circ} \mathrm{C} ; 7 \% ; 2 \mathrm{~h}\right),+1\left(100{ }^{\circ} \mathrm{C} ; 9 \% ; 4\right.$ h), $0\left(90{ }^{\circ} \mathrm{C} ; 8 \% ; 3 \mathrm{~h}\right)$, respectively (Table-2). The coded values of the experimental factors and factor levels were used in the response surface analysis (Table-2). The experiments were carried out in triplicate.

\section{Determination of antioxidant activity}

Reducing power: The reducing power of Maillard reaction products was determined using the method of Yen and Duh with a slight modification ${ }^{17}$. An aliquot $(0.5 \mathrm{~mL})$ of Maillard reaction products (10-fold dilution) was mixed with $2.5 \mathrm{~mL}$ of sodium phosphate buffer $(0.2 \mathrm{M}, \mathrm{pH} 6.6)$ and $2.5 \mathrm{~mL}$ of $1 \%$ potassium ferricyanide. After incubation at $50{ }^{\circ} \mathrm{C}$ for $20 \mathrm{~min}, 2.5 \mathrm{~mL}$ of $10 \%$ trichloroacetic acid (w/v) were added. The mixture was centrifuged at $3000 \mathrm{~g}$ for $10 \mathrm{~min}$. An aliquot $(2.5 \mathrm{~mL})$ of the supernatant was mixed with $2.5 \mathrm{~mL}$ of distilled water and $0.5 \mathrm{~mL}$ of ferric chloride $(0.1 \%)$ and the absorbance at $700 \mathrm{~nm}$ was measured after incubated for $10 \mathrm{~min}$. The absorbance increase is indicative of an increase in the reducing power.

ABTS radical scavenging activity: The method described by Re et al. ${ }^{18}$ with a slight modification was used to measure the ABTS radical scavenging activity. Briefly, 100 $\mu \mathrm{L}$ of Maillard reaction products (10-fold dilution) was mixed with $3 \mathrm{~mL} \mathrm{ABTS}^{\bullet}+$ solution (absorbance of $0.70 \pm 0.01$ at $734 \mathrm{~nm}$ ). The mixture was incubated in dark for $6 \mathrm{~min}$ and the absorbance at $734 \mathrm{~nm}$ was read. The percentage of ABTS radical scavenging activity was calculated as follows:

$\mathrm{ABTS}^{\bullet}+$ Scavenging activity $(\%)=\left(\mathrm{A}_{\mathrm{c}}-\mathrm{A}_{\mathrm{s}}\right) \times 100 / \mathrm{A}_{\mathrm{c}}$

where $A_{c}$ is the absorbance of the control $\left(\mathrm{ABTS}^{\bullet}+\right.$ solution without Maillard reaction products) and $\mathrm{A}_{\mathrm{s}}$ is the absorbance of the sample.

Hydroxide radical scavenging activity: Hydroxide radical scavenging activity was determined according to the method of Lee et al. ${ }^{19}$ with some modifications. Briefly, reaction mixtures containing $1 \mathrm{~mL}$ of phosphate buffer $(0.1 \mathrm{mM}$ ferric chloride, $0.104 \mathrm{mM}$ EDTA, $1.5 \mathrm{mM} \mathrm{H}_{2} \mathrm{O}_{2}, 2.5 \mathrm{mM}$ deoxyribose, $0.1 \mathrm{mM}$ ascorbate, $\mathrm{pH} 7.4$ ) and $0.1 \mathrm{~mL}$ of Maillard reaction products (10-fold dilution) were incubated at $37^{\circ} \mathrm{C}$ for $1 \mathrm{~h}$. Adding $1 \mathrm{~mL}$ of TCA $(2.8 \%)$ and $1 \mathrm{~mL} \mathrm{TBA}(0.5 \%)$. The mixture was incubated at $80^{\circ} \mathrm{C}$ for $0.5 \mathrm{~h}$. The absorbance of the reaction mixtures was measured at $532 \mathrm{~nm}$. The percentage of hydroxide radical scavenging activity was calculated as follows:

Hydroxide radical scavenging activity $(\%)=\left(\mathrm{A}_{\mathrm{c}}-\mathrm{A}_{\mathrm{s}}\right) \times \frac{100}{\mathrm{~A}_{\mathrm{c}}}(2)$ where $A_{c}$ is the absorbance of the control (solution without Maillard reaction products) and $\mathrm{A}_{\mathrm{s}}$ is the absorbance of the sample.

Metal chelation activity: Determination of chelating activity on $\mathrm{Fe}^{2+}$ and $\mathrm{Cu}^{2+}$ chelating activity were determined by the method of Dinis et al..$^{20}$ with modifications.

$\mathrm{Cu}^{2+}$ : The samples were mixed with $1 \mathrm{~mL}$ of $2 \mathrm{mM} \mathrm{CuSO}_{4}$, $1 \mathrm{~mL} 10 \%$ pyridine and $20 \mu \mathrm{L} 0.1 \%$ pyrocatechol violet incubated for $10 \mathrm{~min}$ at room temperature. The amount of free copper in the solutions was obtained from the absorbance ratio $\mathrm{A} 632$.

$\mathrm{Fe}^{2+}$ : One milliliter sample solution was mixed with 1.85 $\mathrm{mL}$ double distilled $\mathrm{H}_{2} \mathrm{O}$ and $0.05 \mathrm{~mL} 2 \mathrm{mM} \mathrm{FeCl}_{2}$, the mixture was allowed to rest at room temperature for $30 \mathrm{~s}$. The reaction mixture thus obtained was later added with $0.1 \mathrm{~mL} 5 \mathrm{mM}$ ferrozine and mixed, absorbance at $562 \mathrm{~nm}$ was determined with spectrophotometer after $10 \mathrm{~min}$ resting time at room temperature and $5 \mathrm{~min}$ centrifugation at $3000 \mathrm{rpm}$. For the blank, the assay was conducted in the same manner but double distilled $\mathrm{H}_{2} \mathrm{O}$ was added instead of sample solution. The percentage of chelating activity was calculated as follows:

Chelating activity $\%=\left(1-\mathrm{A} 562 \mathrm{~nm}_{\text {sample }} / \mathrm{A} 562 \mathrm{~nm}_{\text {blank }}\right) \times 100$ where A562 $\mathrm{nm}_{\text {sample }}$ is the absorbance of sample and A562 $\mathrm{nm}_{\text {blank }}$ is the absorbance of the blank.

Antioxidant activity assay in a liposome system: The antioxidant activity of glycosylated whey protein hydrolyzates was initially assessed by means of thiobarbituric acid-reactive substances (TBARS) analysis in an oxidizing liposome system. Liposomes were prepared from soybean phosphatidylcholine according to the method described by Decker and Hultin ${ }^{21}$. A series of mixed solutions of $5 \mathrm{~mL}$ of a liposome solution with $1 \mathrm{~mL}$ of the glycosylated whey protein hydrolyzates (5-fold dilution) were prepared. The control solution was prepared 
by mixing $1 \mathrm{~mL}$ of water instead of $1 \mathrm{~mL}$ of the glycosylated whey protein hydrolyzates with $5 \mathrm{~mL}$ of the liposome solution. Oxidation was initiated by adding $0.1 \mathrm{~mL}$ of $50 \mathrm{mM} \mathrm{FeCl}$ and $0.1 \mathrm{~mL}$ of $10 \mathrm{mM}$ sodium ascorbate into the liposome/ protein solution. Samples were incubated in a $37{ }^{\circ} \mathrm{C}$ water bath for $1 \mathrm{~h}$ and lipid oxidation was immediately determined using the TBARS analysis procedure. The concentrations of TBARS (secondary products of lipid oxidation), with or without the presence of glycosylated whey protein hydrolyzates, were determined according to the method outlined by Kong and Xiong 22 .

Statistical analysis: All the experiments were run in triplicate. Data were analyzed using the General Linear Models procedure of Statistix 8.1 software package (Analytical Software, St. Paul, MN) for microcomputer. Analysis of variance (ANOVA) was done to determine the significance of the main effects. Significant differences $(\mathrm{P}<0.05)$ between means were identified using Tukey procedures.

\section{RESULTS AND DISCUSSION}

With the aim to achieve the maximum level of whey protein glycosylation, different kinds and concentration of reducing sugar were selected for the glycosylation reaction. Total reducing power is one of the important methods which are utilized to investigate certain materials own in vitro antioxidant activity. Table- 1 show that the glycosylated whey protein hydrolyzates prepared with glucose had higher reducing power than those prepared with lactose and fructose. Fig. 1 show that the changes in reducing power of whey protein hydrolyzates by conjugation with different glucose concentration through Maillard reaction. The antioxidant activity of whey protein glycosylations increased with the increase of the hydrolyzate time. This is consistent with the results of Kim and $\mathrm{Lee}^{23}$. They found that the reducing power of glycosylation product increases with the increase of heating time in the reaction system of glucose and three kinds of amino acids (glycine, glycylglycine, triglycine) (Fig. 1). The antioxidant activity of whey protein glycosylations also increased with the increase of glucose concentration from 3 to $9 \%$. The antioxidant activity of whey protein hydrolyzates conjugation with glucose concentration of 9 and $8 \%$ is higher $(\mathrm{p}<0.05)$ than the concentration from 7 to $3 \%$. When the reaction time is over $3 \mathrm{~h}$, the antioxidant activity of whey protein glycosylations increased slowly. Similar relation of radical-scavenging activity with nature of the sugar was observed by Chevalier et al. ${ }^{24}$.

\begin{tabular}{|c|c|c|c|}
\hline \multicolumn{4}{|c|}{$\begin{array}{c}\text { TABLE-1 } \\
\text { CHANGES IN REDUCING POWER OF VARIOUS } \\
\text { GLYCOSYLATED WHEY PROTEIN HYDROLYZATES } \\
\text { DURING DIFFERENT HEATING TIMES }\end{array}$} \\
\hline \multirow{2}{*}{$\begin{array}{l}\text { Heating times } \\
\text { (h) }\end{array}$} & \multicolumn{3}{|c|}{ Total reducing power $\left(\mathrm{OD}_{700 \mathrm{~mm}}\right)$} \\
\hline & Glucose & Lactose & Fructose \\
\hline 0 & $0.048 \pm 0.003^{\mathrm{eA}}$ & $0.043 \pm 0.009^{\mathrm{eA}}$ & $0.032 \pm 0.025^{\mathrm{dA}}$ \\
\hline 1 & $0.145 \pm 0.027^{\mathrm{dA}}$ & $0.136 \pm 0.011^{\mathrm{dA}}$ & $0.076 \pm 0.008^{\mathrm{cB}}$ \\
\hline 2 & $0.284 \pm 0.003^{\mathrm{cA}}$ & $0.274 \pm 0.014^{\mathrm{cA}}$ & $0.201 \pm 0.012^{\mathrm{bB}}$ \\
\hline 3 & $0.496 \pm 0.021^{\mathrm{bA}}$ & $0.346 \pm 0.012^{\mathrm{bB}}$ & $0.300 \pm 0.022^{\mathrm{abC}}$ \\
\hline 4 & $0.545 \pm 0.014^{\mathrm{aA}}$ & $0.367 \pm 0.035^{\mathrm{bB}}$ & $0.331 \pm 0.014^{\mathrm{aB}}$ \\
\hline 5 & $0.556 \pm 0.051^{\mathrm{aA}}$ & $0.455 \pm 0.022^{\mathrm{aB}}$ & $0.334 \pm 0.054^{\mathrm{aC}}$ \\
\hline \multicolumn{4}{|c|}{$\begin{array}{l}\text { Note: }{ }^{\text {a-e }}: \text { means with the different letter within a row are significant } \\
\text { difference }(\mathrm{P}<0.05) ;{ }^{A-C} \text { : means with the different letter within a } \\
\text { column are significant difference }(\mathrm{P}<0.05) \text {. }\end{array}$} \\
\hline
\end{tabular}

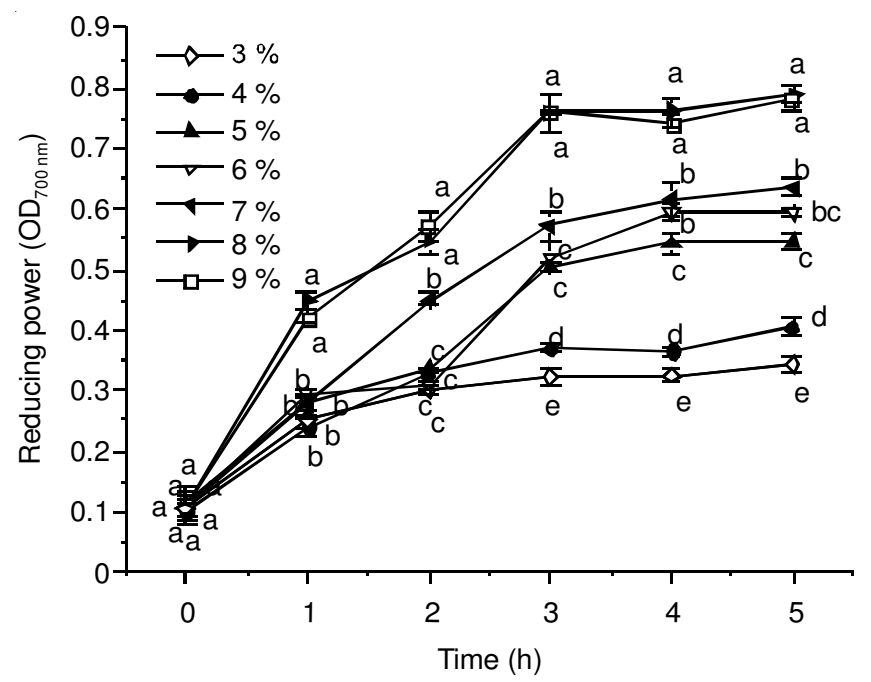

Fig. 1. Changes in reducing power of various glucose concentration glycosylated whey protein hydrolyzates during different heating times Note: ${ }^{\text {a-e }}$ : means with the different letter within the same time are significant difference $(\mathrm{P}<0.05)$

Effect of temperature on reducing power: Fig. 2 shows that the changes in reducing power of various glycosylated whey protein hydrolyzates during different heating temperature. The antioxidant activity of whey protein glycosylations increased with the increase of the temperature and reaction time. The antioxidant activity of whey protein hydrolyzates conjugation with glucose at temperature of $90^{\circ} \mathrm{C}$ is higher ( $\mathrm{p}$ $<0.05$ ) than the temperature from 50 to $80^{\circ} \mathrm{C}$. This result is maybe due to the ascending temperature was significantly modified in the conjugate solution system, which should be ascribed to the changes in whey protein denaturation and aggregation behaviour upon the attachment of glucose ${ }^{25}$. The antioxidant activity of whey protein hydrolyzates conjugation with glucose is also increased with the increase of reaction time.



Fig. 2. Changes in reducing power of various glycosylated whey protein hydrolyzates during different heating temperature and times [Note: ${ }^{\mathrm{a}-\mathrm{d}}$ : means with the different letter within the same time are significant difference $(\mathrm{P}<0.05)]$

Optimum reaction conditions: Glucose concentration, reaction time and reaction temperature were considered as the three factors; three-factor to three-level response surface 
experiment is designed to identify the optimum reaction conditions, the optimum reaction conditions are shown in Table-2.

TABLE-2

\begin{tabular}{lccc}
\multicolumn{2}{c}{ TABLE-2 } \\
CODED VALUES OF CORRESPONDING ACTUAL VALUES OF \\
INDEPENDENT VARIABLES IN RESPONSE SURFACE DESIGN \\
\cline { 2 - 4 } \multicolumn{1}{c}{ Factor } & -1 & 0 & 1 \\
\hline & 80 & 90 & 100 \\
\hline Temperature $\left({ }^{\circ} \mathrm{C}\right)$ & 7 & 8 & 9 \\
Glucose concentration $(\%)$ & 2 & 3 & 4 \\
Time (h) & & & \\
\hline
\end{tabular}

According to Box Benhnken's central composite experiment design principles, on the basis of the single-factor experimental study, temperature, glucose concentration and reaction time were selected as the independent variable, total reducing power as the evaluating indicator, to design 17 groups of threefactor to three-level response surface experiments, among which 13 are factorial experiments and 4 are central experiments which are used to estimate the experimental error. Experimental scheme and results are shown in Table-3. Table- 4 shows that the results of regression analysis and variance analysis.

\begin{tabular}{|c|c|c|c|c|}
\hline \multicolumn{5}{|c|}{$\begin{array}{c}\text { TABLE-3 } \\
\text { DESIGN AND RESULTS OF THE RESPONSE } \\
\text { SURFACE METHODOLOGY }\end{array}$} \\
\hline $\begin{array}{l}\text { Sequence } \\
\text { number }\end{array}$ & $\begin{array}{c}\mathrm{C} \text { (glucose } \\
\text { concentration) }\end{array}$ & $\begin{array}{c}\text { B } \\
\text { (temp.) }\end{array}$ & $\underset{\text { (time) }}{\mathrm{A}}$ & $\begin{array}{l}\mathrm{Y} \text { (total } \\
\text { reducing power) } \\
\left(\mathrm{OD}_{700 \mathrm{~mm}}\right)\end{array}$ \\
\hline 1 & 9.000 & 90.000 & 4.000 & 0.906 \\
\hline 2 & 8.000 & 100.000 & 2.000 & 0.873 \\
\hline 3 & 8.000 & 90.000 & 3.000 & 0.871 \\
\hline 4 & 9.000 & 100.000 & 3.000 & 0.89 \\
\hline 5 & 8.000 & 80.000 & 2.000 & 0.782 \\
\hline 6 & 8.000 & 90.000 & 3.000 & 0.969 \\
\hline 7 & 8.000 & 90.000 & 3.000 & 0.953 \\
\hline 8 & 7.000 & 100.000 & 3.000 & 0.895 \\
\hline 9 & 7.000 & 80.000 & 3.000 & 0.835 \\
\hline 10 & 8.000 & 100.000 & 4.000 & 0.918 \\
\hline 11 & 7.000 & 90.000 & 4.000 & 0.824 \\
\hline 12 & 8.000 & 80.000 & 4.000 & 0.851 \\
\hline 13 & 7.000 & 90.000 & 2.000 & 0.903 \\
\hline 14 & 9.000 & 80.000 & 3.000 & 0.818 \\
\hline 15 & 9.000 & 90.000 & 2.000 & 0.829 \\
\hline 16 & 8.000 & 90.000 & 3.000 & 0.964 \\
\hline 17 & 8.000 & 90.000 & 3.000 & 0.976 \\
\hline
\end{tabular}

Through the analysis of the statistical analysis software Statistix 8.1, the quadratic regression model was obtained:

$\mathrm{Y}=0.947-0.00175 \mathrm{~A}+0.03625 \mathrm{~B}+0.014 \mathrm{C}-0.0388 \mathrm{~A}^{2}$ $-0.0483 B^{2}-0.0423 C^{2}+0.003 A B+0.039 A C-0.006 B C$

Table- 4 shows that the effect of $\mathrm{B}, \mathrm{A}^{2}, \mathrm{~B}^{2}, \mathrm{AC}$ terms were significant $(\mathrm{P}<0.05)$. This indicates that in the linear terms, reaction time has a significant effect on the experiment results $(\mathrm{P}<0.05)$; in the interaction terms, glucose concentration and reaction time have a significant mutual effect on the experiment results $(\mathrm{P}<0.05)$; and in the quadratic terms, both glucose
TABLE-4

VARIANCE ANALYSIS FOR THE FITTED REGRESSION EQUATION

\begin{tabular}{ccccccc}
\hline Factor & DF & $\begin{array}{c}\text { Coefficient } \\
\text { estimate }\end{array}$ & $\begin{array}{c}\text { Sum of } \\
\text { Squares }\end{array}$ & $\begin{array}{c}\text { Mean } \\
\text { Square }\end{array}$ & F Value & P Value \\
\hline Model & 9 & 0.9466 & 0.0448 & 0.0050 & 3.7466 & 0.0477 \\
$\mathrm{~A}$ & 1 & -0.0018 & $2.45 \mathrm{E}-05$ & $2.45 \mathrm{E}-05$ & 0.0184 & 0.8958 \\
$\mathrm{~B}$ & 1 & 0.0363 & 0.0105 & 0.0105 & 7.9091 & 0.0261 \\
$\mathrm{C}$ & 1 & 0.0140 & 0.0016 & 0.0016 & 1.1797 & 0.3134 \\
$\mathrm{~A}^{2}$ & 1 & -0.0388 & 0.0063 & 0.0063 & 4.7689 & 0.0653 \\
$\mathrm{~B}^{2}$ & 1 & -0.0483 & 0.0098 & 0.0098 & 7.3901 & 0.0298 \\
$\mathrm{C}^{2}$ & 1 & -0.0423 & 0.0075 & 0.0075 & 5.6681 & 0.0488 \\
$\mathrm{AB}$ & 1 & 0.0030 & $3.6 \mathrm{E}-05$ & $3.6 \mathrm{E}-05$ & 0.0271 & 0.8739 \\
$\mathrm{AC}$ & 1 & 0.0390 & 0.0061 & 0.0061 & 4.5773 & 0.0697 \\
$\mathrm{BC}$ & 1 & -0.0060 & 0.0001 & 0.0001 & 0.1083 & 0.7517 \\
Residual & 7 & \multicolumn{7}{c}{0.0093} & 0.0013 & & \\
Lack of fit & 3 & 0.0019 & 0.0006 & 0.3374 & 0.8006 \\
Pure error & 4 & 0.0074 & 0.0019 & & \\
Cor total & 16 & \multicolumn{7}{c}{0.0541} & & & \\
$\mathrm{R}^{2}$ & \multicolumn{7}{c}{0.828} \\
\hline
\end{tabular}

concentration and reaction temperature have a significant effect on the experiment results $(\mathrm{P}<0.05)$. The concrete mutual functions are shown from Figs. 3 to 5 .

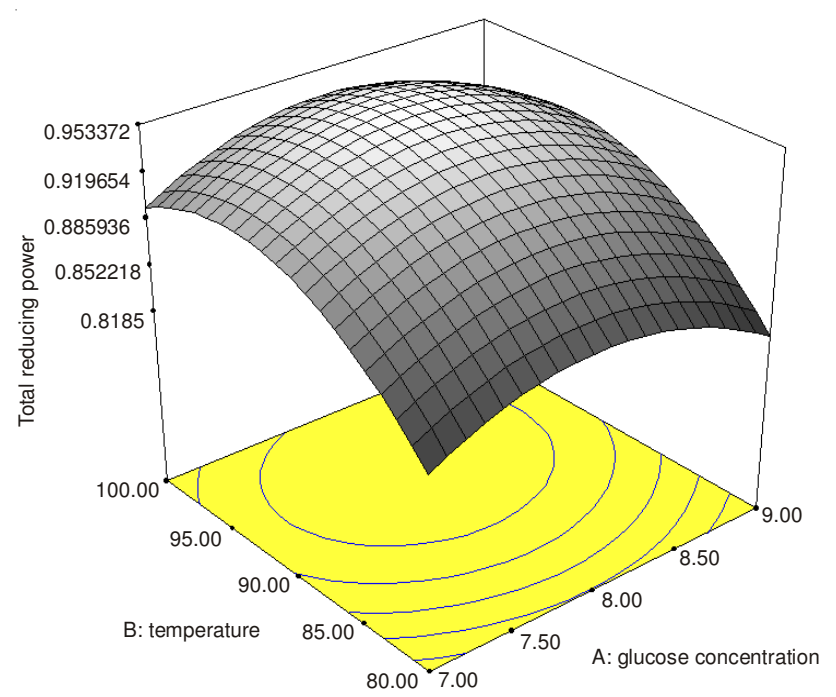

Fig. 3. Response surface stereogram of temperature (B) and glucose concentration (A)

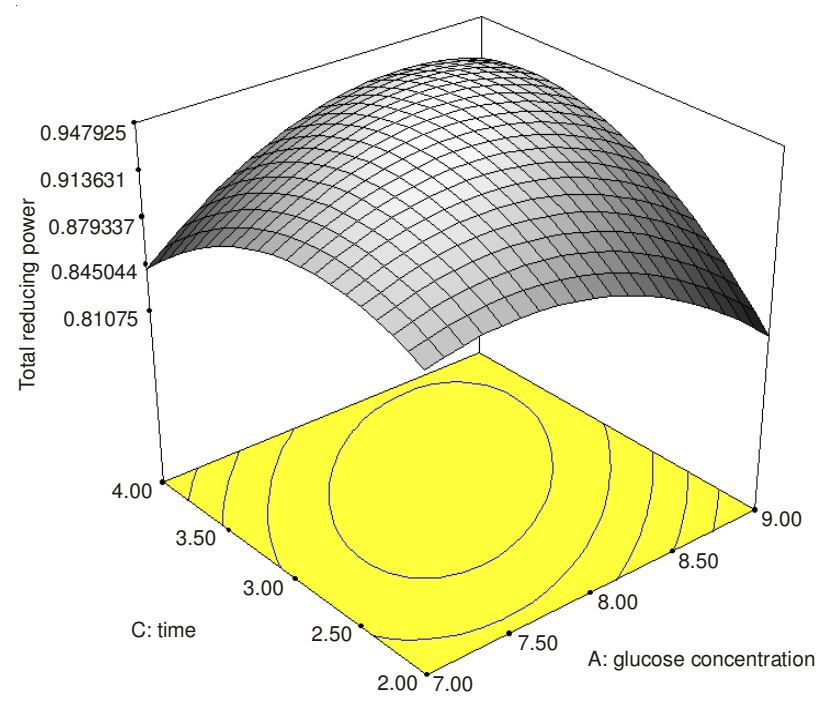

Fig. 4. Response surface stereogram of time (C) and glucose concentration (A) 


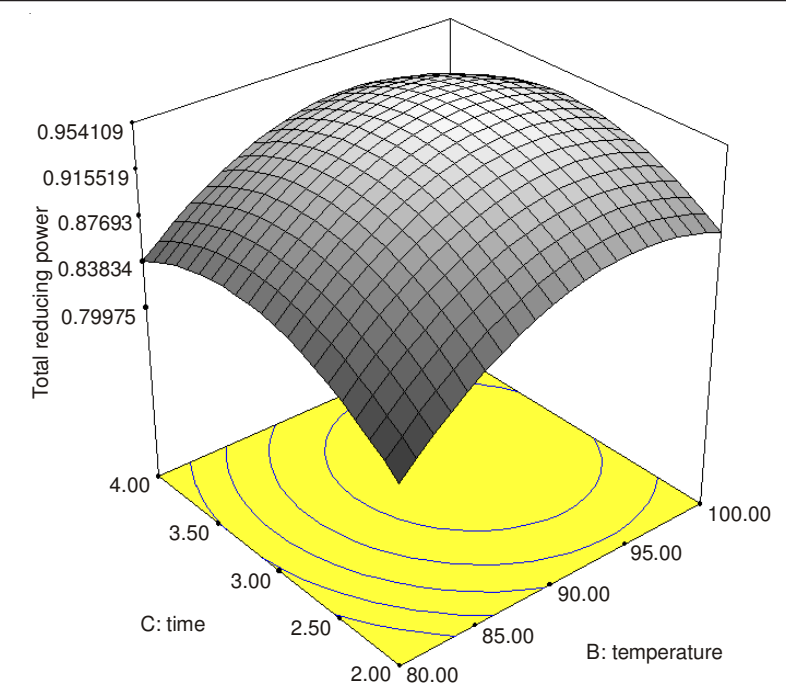

Fig. 5. Response surface stereogram of time (C) and temperature (B)

Table-4 shows the results of variance analysis, because the linear relations are obvious between the variables and the independent variables, the model regression is evident $(\mathrm{P}<$ $0.05)$. The model $\mathrm{R}^{2}$ equals 0.828 , indicating that the model is well fit for the experiment. The $p$ test also was used to evaluate the significance of the parameters for the model and the lack of fit, there was no significance in the lack of fit $(p=0.8006)$ in the model. This indicated that the models could be used to predict responses ${ }^{26}$. The linear relations are obvious between the independent variables and the response values and so it can be applied in the theoretical prediction of the reaction. Getting differentiation for regression equation and making it equals zero can get the maximum point of the surface, the optimum level values of the three major factors is following: glucose concentration is 8.08 , temperature is $93.68{ }^{\circ} \mathrm{C}$ and time is $3.18 \mathrm{~h}$. The optimum reducing power of the response surface is 0.954 .

In order to fit the practical productive conditions, the above conditions were corrected: glucose concentration is $8 \%$, temperature is $94{ }^{\circ} \mathrm{C}$ and reaction time is $3.2 \mathrm{~h}$. Under such conditions we did the identification experiment and the reducing power is 0.939 as a result, whose reproducibility is better than the theoretical prediction (Table-5).

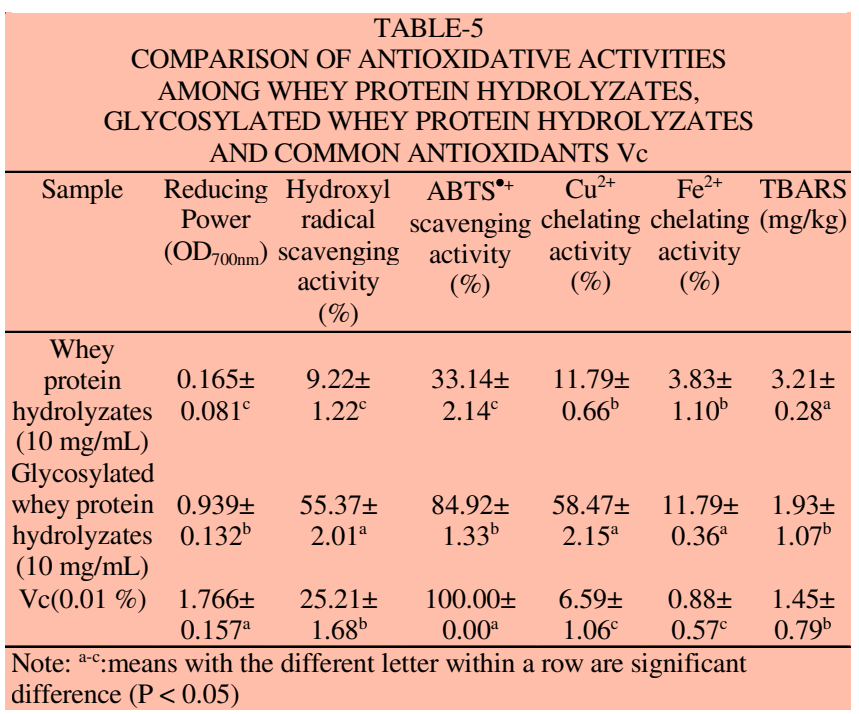

Comparison of antioxidant activities of whey protein hydrolyzates by conjugation with glucose through Maillard reaction under the optimum condition: Antioxidant activity was analysed by determination of the reducing power, hydroxyl radical scavenging activity, scavenging of the ABTS radical, Copper and iron chelating activities of whey protein hydrolyzates by conjugation with glucose through Maillard reaction and whey protein hydrolyzates (Table-5). The comparison results of the antioxidant activities of whey protein hydrolyzates by conjugation with glucose through Maillard reaction and antioxidant $\mathrm{V}_{\mathrm{c}}$ are shown in Table-5. Reducing power was determined by measuring reduction of the $\mathrm{Fe}^{3+} /$ ferricyanide complex to the ferrous form, which was monitored by measuring the formation of Perl's Prussian blue at $700 \mathrm{~nm}$. The reducing power of whey protein hydrolyzates by conjugation with glucose $(0.939)$ is higher $(\mathrm{P}<0.05)$ than that of whey protein hydrolyzates $(0.165)$. The hydroxyl radical scavenging activity of whey protein hydrolyzates by conjugation with glucose $(55.37 \%)$ is higher $(\mathrm{P}<0.05)$ than that of whey protein hydrolyzates $(9.22 \%)$. The ABTS decolorization assay can be used to determine antioxidant activity of both lipophilic and hydrophilic molecules and is based on the reaction of hydrogen donating antioxidants with the $\mathrm{ABTS}^{+}$radical, which is intensely coloured and is determined by measuring absorbance at $734 \mathrm{~nm}$. The $\mathrm{ABTS}^{+}$of whey protein hydrolyzates by conjugation with glucose $(84.92 \%)$ is higher $(\mathrm{P}<0.05)$ than that of whey protein hydrolyzates $(33.14 \%)$. Similar results were observed by Beermann et al. ${ }^{27}$. These data are consistent with reports that the radical scavenging mechanism depends on the presence of hydrophobic amino acids ${ }^{28}$. Chelation of metal ions has an antioxidant effect because the transition metals iron and copper catalyze the generation of reactive oxygen species, including hydroxyl radical $\left({ }^{\square} \mathrm{OH}\right)$ and superoxide radical $\left(\mathrm{O}_{2}^{\mathrm{Q}}\right)$, leading to oxidation of unsaturated lipids and promoting oxidative damage at different levels ${ }^{29}$. The $\mathrm{Cu}^{2+}$ chelating activity and $\mathrm{Fe}^{2+}$ chelating activity of whey protein hydrolyzates by conjugation with glucose is 58.47 and 11.79 $\%$, respectively. The $\mathrm{Cu}^{2+}$ chelating activity and $\mathrm{Fe}^{2+}$ chelating activity of whey protein hydrolyzates by conjugation with glucose is higher $(\mathrm{P}<0.05)$ than that of whey protein hydrolyzates. This result may be due to the whey protein was hydrolyzed and produced some small peptides; small peptides can provide the highest copper chelating activity ${ }^{30}$. The TBARS of whey protein hydrolyzates by conjugation with glucose is also higher $(\mathrm{P}<0.05)$ than that of whey protein hydrolyzates. Table- 5 showed that whey protein hydrolyzates by conjugation with glucose demonstrated high antioxidant activities.

\section{Conclusion}

A factorial design was applied to optimize the antioxidant activities of whey protein hydrolyzates by conjugation with glucose. The operational conditions selected to obtain significant antioxidant properties were glucose concentration is $8 \%$, temperature is $94{ }^{\circ} \mathrm{C}$ and reaction time is $3.2 \mathrm{~h}$. Under this optimum condition, whey protein hydrolyzates by conjugation with glucose through Maillard reaction showed high antioxidant activities than whey protein hydrolyzates. 


\section{ACKNOWLEDGEMENTS}

This study was supported by the Research Fund of Young Scholars for the Doctoral Program of Higher Education of China (Grant No. 20122325120018), and the Foundation for University Key Teacher of the Heilongjiang Educational Committee (Grant No. 1253G007).

\section{REFERENCES}

1. E.A. Foegeding, J.P. Davis, D. Doucet and M.K. McGuffey, Trends Food Sci Technol., 13, 151 (2002).

2. M. Hattori, Y. Aiba, K. Nagasawa and K. Takahashi, J. Food Sci., 61, 1171 (1996).

3. Nagasawa, Takahashi Hattori, . K. Nagasawa, K. Takahashi and M. Hattori, Food Hydrocoll., 10, 63 (1996).

4. C.M. Oliver, L.D. Melton and R.A. Stanley, Food Sci. Nutr., 46, 337 (2006).

5. L. Jiménez-Castaño, M. Villamiel, P.J. Martín-Alvarez, A. Olano, and R. López-Fandiño, Food Hydrocoll., 19, 831 (2005).

6. E. Dickinson and V.B. Galazka, Food Hydrocoll., 5, 281 (1991).

7. C.A. Dunlap and G.L. Cote, J. Agric. Food Chem., 53, 419 (2005).

8. A. Kato, Y. Sasaki, R. Furuta and K. Kobayashi, Agric. Biol. Chem., 54, 107 (1990)

9. Y. Shu, S. Sahara, S. Nakamura and A. Kato, J. Agric. Food Chem., 44, 2544 (1996)

10. F. Chevalier, J.M. Chobert, C. Genot and T. Haertlé, J. Agric. Food Chem., 49, 5031 (2001).

11. K. Damianou and V. Kiosseoglou, Food Hydrocoll., 20, 793 (2006).
12. Y. Sun, S. Hayakawa and K. Izumori, J. Agric. Food Chem., 52, 1293 (2004).

13. T.J. Wooster and M.A. Augustin, J. Colloid Interf. Sci., 303, 564 (2006).

14. T.J. Wooster and M.A. Augustin, J. Colloid Interf. Sci., 313, 665 (2007).

15. E.A. Peña-Ramos and Y.L. Xiong, J. Dairy Sci., 84, 2577 (2001).

16. T. Juntachote, E. Berghofer, F. Bauer and S. Siebenhandl, Int. J. Food Sci. Technol., 41, 121 (2006).

17. G.C. Yen and P.D. Duh, J. Am. Oil Chem. Soc., 70, 383 (1993).

18. R. Re, N. Pellegrini, A. Proteggente, A. Pannala, M. Yang and C. RiceEvans, Free Radic. Biol. Med., 26, 1231 (1999).

19. J.C. Lee, H.R. Kim, J. Kim and Y.S. Jang, J. Agric. Food Chem., 50, 6490 (2002).

20. T.C.P. Dinis, V.M.C. Madeira and L.M. Almeida, Arch. Biochem. Biophys., 315, 161 (1994).

21. E.A. Decker and H.O. Hultin, J. Food Sci., 55, 947 (1990).

22. B.H. Kong and Y.L. Xiong, J. Agric. Food Chem., 54, 6059 (2006).

23. J.S. Kim and Y.S. Lee, Food Chem., 116, 227 (2009).

24. F. Chevalier, J.M. Chobert, Y. Popineau, M.G. Nicolas and T. Haertlé, Int. Dairy J., 11, 145 (2001).

25. W.W. Sun, S.J. Yu, X.Q. Yang, J.M. Wang, J.B. Zhang, Y. Zhang and E.L. Zheng, Food Res. Int., 44, 3259 (2011)

26. J. Saha, A. Biswas, A. Chhetri and P.K. Sarkar, Food Chem., 129, 507 (2011).

27. C. Beermann, M. Euler, J. Herzberg and B. Stahl, Eur. Food Res. Technol., 229, 637 (2009).

28. A. Jimenez-Escrig, M. Alaiz, J. Vioque and P. Ruperez, Eur. Food Res. Technol., 230, 655 (2010).

29. A. Saiga, S. Tanabe and T. Nishimura, J. Agric. Food Chem., 51, 3661 (2003).

30. C. Torres-Fuentes, M. Alaiz and J. Vioque, Food Chem., 129, 485 (2011). 